\title{
EFFECTS OF EXTRUSION SHEAR ON THE MICROSTRUCTURES AND A FRACTURE ANALYSIS OF A MAGNESIUM ALLOY IN THE HOMOGENIZED STATE
}

\author{
VPLIVI STRIŽENJA MED IZTISKANJEM HOMOGENIZIRANE \\ MAGNEZIJEVE ZLITINE NA MIKROSTRUKTURO IN NA \\ ANALIZO PRELOMA
}

\author{
Hongjun $\mathrm{Hu}^{1}$, Zhao Sun ${ }^{1}$, Dingfei Zhang ${ }^{2}$ \\ ${ }^{1}$ Chongqing University of Technology, College of Material Science and Engineering, 400050, P.R.China \\ ${ }^{2}$ Chongqing University, National Engineering Research Center for Magnesium Alloys, 400044, P.R.China \\ 48516686@qq.com \\ Prejem rokopisa - received: 2015-04-16; sprejem za objavo - accepted for publication: 2015-05-21
}

doi: $10.17222 /$ mit.2015.081

\begin{abstract}
A new type composite extrusion method has been explored that combines extrusion and two continuous shears (referred to as Extrusion-Shear (ES)). To study the effects of extrusion-shear on the microstructures and the mechanical properties of a magnesium alloy for homogenization state, the ES process has been performed on extrusion equipment using an ES die. Grain-size measurements and X-ray diffraction and compression experiments were conducted. The experimental results and fracture analyses were described and discussed. It was found that the microstructures could be refined gradually from part 1 to 4 in the ES die. But a higher temperature could improve the grain growth and coarsen the microstructures. The results showed that fine and uniform microstructures can be achieved using the (ES) process and various types of texture can also be found in the microstructures. From the X-Ray diffraction (0002) the basal plane texture intensity was decreased, and the ES process could weaken the dominant base texture for $(0002)$. The main fracture mechanism for the specimens extruded at $420{ }^{\circ} \mathrm{C}$ is transgranular fracture, while it is primarily caused by twins when the extrusion temperature was $450{ }^{\circ} \mathrm{C}$.

Keywords: magnesium alloy, microstructure, texture, grain size, fracture analysis
\end{abstract}

Uporabljena je bila nova vrsta sestavljene metode iztiskovanja, ki kombinira iztiskovanje in dvojno kontinuirano striženje (ES). Za študij vpliva striženja na mikrostrukturo pri iztiskanju in na mehanske lastnosti magnezijeve zlitine $\mathrm{v}$ homogeniziranem stanju, je bil izvršen ES postopek na napravi za iztiskovanje, z uporabo ES orodja. Izvedene so bile meritve velikosti zrn in rentgenska difrakcija stisnjenih vzorcev. Opisani in ocenjeni so bili rezultati preizkusov in analize preloma. Ugotovljeno je, da le-to postaja mikrostruktura bolj drobnozrnata od 1 do $4 \mathrm{v}$ ES orodju. Višje temperature lahko olajšajo rast zrn, kar napravi mikrostrukturo bolj grobozrnato. Rezultati so pokazali, da je mogoče drobnozrnato in enakomerno mikrostrukturo doseči s postopkom striženja pri iztiskovanju (ES), v mikrostrukturi pa je moč najti različne vrste tekstur. Iz rentgenske difrakcije se vidi, da intenziteta teksture osnovne ravnine (0002) slabi in da ES postopek zmanjša prevlado osnovne teksture za (0002). Glavni mehanizem preloma vzorcev, iztiskanih pri $420{ }^{\circ} \mathrm{C}$, je transkristalni prelom. Slednjega povzročajo predvsem dvojčki, če je temperatura iztiskanja $450{ }^{\circ} \mathrm{C}$.

Ključne besede: magnezijeva zlitina, mikrostruktura, tekstura, velikost zrn, analiza preloma

\section{INTRODUCTION}

A magnesium alloy is increasingly being specified for automotive, transportation, electronics, aerospace, and general engineering applications. ${ }^{1}$ Magnesium has the ability to combine a high strength and a lighter weight..$^{2-4}$ But the use of magnesium alloys in aerospace and military applications has begun to decline due to the poor service performance. ${ }^{5,6} \mathrm{~A}$ new type of composite extrusion method has been explored that combines extrusion and shear (referred to as ES). The ES process and the die design and optimization in production practice were obtained by repeated testing on industrial extruders. To study the effects of ES on microstructures and the mechanical properties of a magnesium alloy for the as-cast and homogenized state of magnesium alloys during the ES process, the ES process was performed on extrusion equipment with an ES die. The grain size measurement and the X-ray diffraction analysis and compression experiments and fracture analysis were made and discussed.

\section{EXPERIMENTAL PART}

A homogenizing treatment was conducted for AZ31 magnesium alloys ( $\mathrm{Mg} 3.02 \% \mathrm{~A} 11.01 \% \mathrm{Zn} 0.30 \% \mathrm{Mn})$, the microstructures of the homogenized state were observed, and the ES processes were performed with different preheated temperatures. The metallurgical experiment, grain size measurement, mechanical property tests and X-ray diffraction analysis were conducted on an extruded AZ31 magnesium alloy. The AZ31 magnesium alloys in the homogenized state were chosen as the materials for the experiment. The material used in this study is the AZ31B Mg alloy. The proof stress of the AZ31 wrought Mg alloy is typically $160-240 \mathrm{MPa}$, and 
the $\mathrm{Mg}$ alloy has a lower density and can withstand greater column loading per unit weight. The billets were machined into rounds with a diameter of $80 \mathrm{~mm}$. The process parameters in the manufacturing process are critical to the microstructure evolution and the mechanical properties.

After the homogenization annealing treatment, the specimen and the die were heated to the desired temperatures and kept for $1 \mathrm{~h}$. The experiments were made by pressing with a force of 500 tons on the horizontal extrusion machines with a container diameter of $85 \mathrm{~mm}$. The ES process was conducted with an extrusion speed of $0.5 \mathrm{~m} / \mathrm{min}$. The microstructures of the AZ31 magnesium alloy for the homogenized state with preheated temperatures $450{ }^{\circ} \mathrm{C}$ and $420{ }^{\circ} \mathrm{C}$ for the magnesium alloy, respectively, were observed using a metallographic microscope.

Immediately after the ES processes the rods and die were water quenched in order to fix the metallurgical microstructures, and then the ES die and formed rods, including the billet remaining in ES die, were cut along the plane of symmetry. In order to study the changes of the microstructures at all stages of the ES process, samples taken from products in different parts of the ES die were observed, including microstructural observations and an analysis of the planes that are parallel to the extrusion direction.

All samples were grinded, first coarsely, then finely, with waterproof abrasive paper, no.120, no.280, no.400, no.600, no.800, no.1000, and no.1200. The etchant employed in this experiment was a picric-acid-based etchant including $5 \mathrm{~g}$ picric acid, $5 \mathrm{~g}$ acetic acid, $100 \mathrm{~mL}$ alcohol and $10 \mathrm{~mL}$ distilled water. The microstructures were observed under the electron microscope. The specimens used for the metallographic observation and the X-ray diffraction analysis were taken from the parts shown in Figure 1. Deformation zone 1 is located within the compression cone, deformation zone 2 is through the

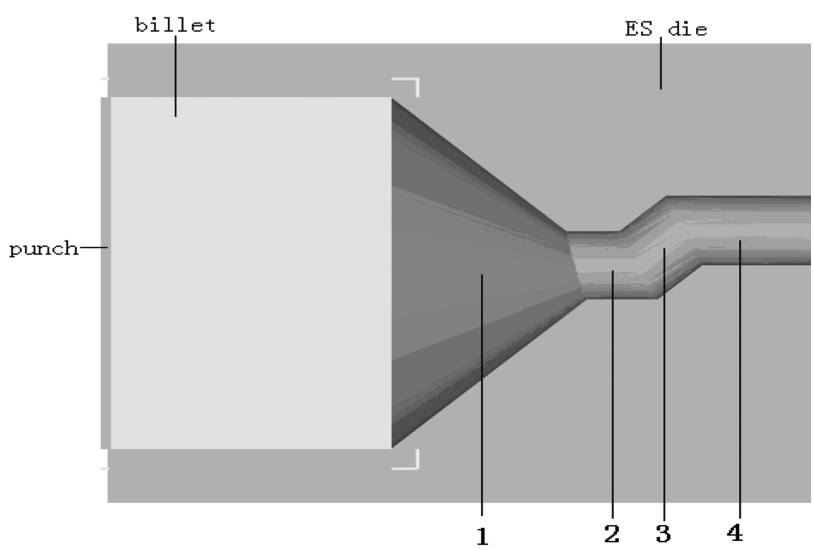

Figure 1: Schematic diagram of ES die with two $120^{\circ}$ corner angles, 1 - upsetting zone, 2 - sizing zone, 3 - the first shearing zone, 4 - the second shearing zone

Slika 1: Shematski prikaz ES z dvema zamikoma s kotom $120^{\circ}$ : 1 - področje krčenja, 2 - področje dimenzioniranja, 3 - prvo področje striženja, 4 - drugo področje striženja compression cone, deformation zone 3 is the first shearing zone, and deformation zone 4 is the second shearing zone.

An Olympus light microscope was employed to observe the microstructure. The average grain size $(\bar{d})$ of the microstructure was measured with the cut straightline method, which is a test method using the "average intercept length" ( $L$ ) to represent the grain size, where the $L$ can be determined on the polishing plane. The average intercept length of the grains filling the space is as follows: ${ }^{7}$

$$
L=1 / N L=L T / P M
$$

where $N L$ is the number of grains per unit test line length, $M$ is the macrostructure magnification, $L T$ is the total length of any test lines that get through the microstructure image and $P$ is the intersection number of test lines and the grain boundaries.

The mechanical properties experiments were performed on a CMT-5150 universal electronic testing machine, including compression and tensile failure experiments that were conducted at a speed of $1 \mathrm{~mm} / \mathrm{min}$. Before the experiments, deformed specimens were machined into standard compression specimens and tensile specimens with dimensions of $\Phi 8 \times 16 \mathrm{~mm}$ and $\delta 5$, respectively. The tensile and compression fracture tests were conducted to obtain the yield strength, tensile strength, compressive strength, elongation after fracture and the compression ratio of the extruded magnesium alloy. The crystallographic orientation of the homogenized and extruded AZ31 magnesium alloy rod wasen analyzed qualitatively by X-ray diffraction, which was used to determine the crystallographic orientation of the rods. ${ }^{8}$ Each diffraction peak was calibrated according to the standard X-ray diffraction chart to determine the Miller indices corresponding to the diffraction peaks. The experiments were conducted on a D/Max-1200X $\mathrm{X}$-ray diffractometer, using a scanning angle of $20-80^{\circ}$, a scanning speed of $1^{\circ} \mathrm{min}^{-1}$, a $\mathrm{Cu}$ target, an acceleration voltage of $40 \mathrm{kV}$, a filament current of $30 \mathrm{~mA}$ and graphite monochromatic as the filter.

\section{RESULTS AND DISCUSSION}

By comparing the grain sizes from the cross-sections of the magnesium alloy billet after the ES process, it is clear that the grains were significantly refined because the dynamic recrystallization happens during the ES process. In addition, it can also be seen from Figure 2 that the grains are constantly refined from part 1 to 4 in Table 1, and the grain sizes are compared in the same part with different extrusion temperatures. It is well known that the grain size increases with the temperature, which is because a higher temperature would improve the grain growth. ${ }^{8,9}$

The lamellar microstructures in the first shear zone begin to reduce for the large shear strain caused by the 

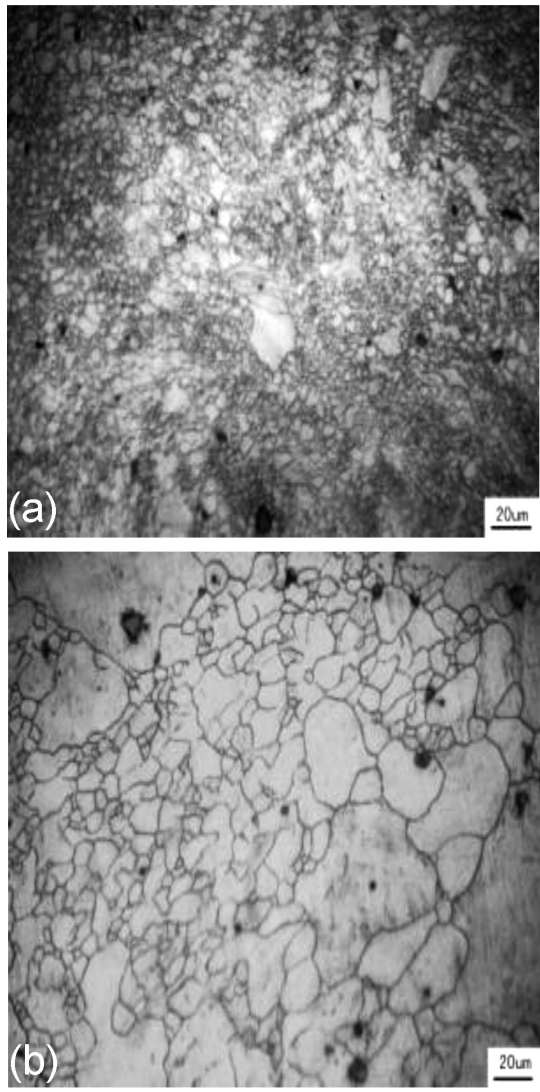

Figure 2: Microstructures of the cross-section with preheated temperatures: a) $420{ }^{\circ} \mathrm{C}$, b) $450{ }^{\circ} \mathrm{C}$

Slika 2: Mikrostrukturi preseka pri temperaturi ogrevanca: a) $420{ }^{\circ} \mathrm{C}$, b) $450{ }^{\circ} \mathrm{C}$

Table 1: Comparison of the grain size during various stages for the ES process

Tabela 1: Primerjava velikosti zrn med različnimi stopnjami ES postopka

\begin{tabular}{|c|c|c|c|c|c|c|}
\hline & $\begin{array}{c}\text { Homogeniza- } \\
\text { tion state }\end{array}$ & $\begin{array}{c}\text { Tempe- } \\
\text { rature }\end{array}$ & Part 1 & Part 2 & Part 3 & Part 4 \\
\hline $\begin{array}{c}\text { Grain size } \\
(\mu \mathrm{m})\end{array}$ & 188 & $420^{\circ} \mathrm{C}$ & 4.9 & 2.8 & 2.4 & 2.1 \\
\cline { 2 - 7 } & $450{ }^{\circ} \mathrm{C}$ & 8.8 & 8.1 & 5.6 & 5.0 \\
\hline
\end{tabular}

shear deformation in this zone and the deformed grains turn into recrystallization grains. In the second shear zone, DRX occurs, but there is still a small amount of fine-grain strips in the center of the rod. The average grain size decreased from about $188 \mu \mathrm{m}$ to $2-5 \mu \mathrm{m}$ by using the ES process. The microstructures are not only greatly refined but also relatively uniform because the ES process includes two simple shear steps. The deformation degree of the central parts of the rods increases, allowing more DRX to occur. Therefore, the microstructure becomes smaller and more homogeneous.

From the microstructures of the billet after the ES process it can be observed that the number of dendrites in the $\alpha-\mathrm{Mg}$ matrix is greatly reduced, while the second phase and the dendrites' segregation were mostly eliminated in the microstructures. The sizes of the grains before and after the ES process were measured using the cut line method, as shown in Table $\mathbf{1}$.

The relationship between the average recrystallization grain size $(d)$ and the Zener-Hollomon parameter $(Z)$ during the dynamic recrystallization is given by $-\ln d=$ $\mathrm{A}+\mathrm{B} \ln Z$. Based on the present ES process, with the extrusion temperature, the accumulative strain increase with the extrusion advancing, the grains will be refined. ${ }^{10,11}$

The relationship between the average recrystallization grain size $(d)$ and the Zener-Hollomon parameter $(Z)$ during dynamic recrystallization is given by Equation (1):

$$
\left(\frac{d}{d_{0}}\right)^{n}=10^{-3} \cdot Z^{-1 / 3}
$$

The temperature-corrected strain rate $Z$ is given by Equation (2):

$$
Z=\varepsilon \exp \left(\frac{Q}{R T}\right)
$$

where $\varepsilon$ is the strain rate, $Q$ is the activation energy for the deformation, $T$ is the temperature and $R$ is the gas constant.

It can be seen from Equation (1) and Equation (2) that the preheated temperature of the billets has a significant impact on the dynamic recrystallization of the fine grains if the structure parameters of the ES dies are the same. So the sizes and the volume fraction of the dynamic recrystallization of the fine grains are inversely proportional to the preheated temperature of the billets. It is obvious that the average sizes of the grains for the lower preheated temperature are finer than those of the higher preheated temperature. It can be observed that the lower temperature could inhibit any further grain growth.

To obtain the orientations of the deformed grains, XRD tests were carried out. The baseline orientation was obtained by using samples that were taken from the longitudinal section in a direction parallel to the extrusion direction of the ES process. The strength of the diffraction lines represents the relative amount of the crystal plane that is parallel to the distribution surface. As can be seen from Figure 3, the strongest diffraction peak is the (0002) crystal plane, and the (1010) plane is the second-strongest diffraction peak before the ES process. In $\mathrm{Mg}$ alloys, a strong basal texture is always found, which resulted in poor ductility at room temperature. Therefore, it is important to control the orientations during the processing. In the upsetting zone I, the strongest diffraction peak is still the (0002) crystal plane. But in the sizing zone, the intensity of the (1010) and (1011) planes increases very obviously. The crystal plane (1011) is the strongest diffraction peak in the last two continuous shearing zones, while the strength of the basal plane (0002) peak clearly decreases. The two shearing steps lead to an increase in the peak-intensity ratio. This shows that the ES process could promote the coexistence 


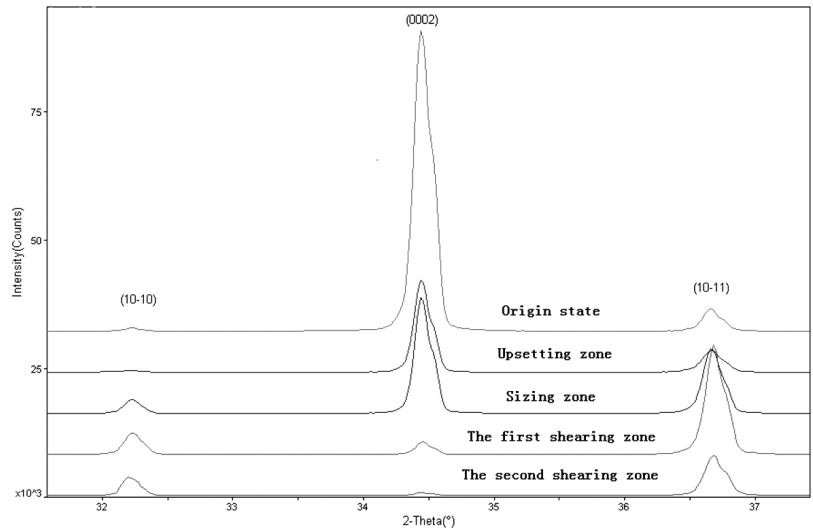

Figure 3: X-Ray diffraction of AZ31 Mg alloy in different parts of the rod in ES dies

Slika 3: Rentgenska difrakcija Mg zlitine AZ31 na različnih delih palice $v$ ES orodju

of the (0002) basal plane and the non-basal planes. From the XRD test, it is clear that the basal texture of (0002) was greatly weakened, and it becomes less dominant after the ES process. The weakening of the basal texture could be attributed to the shear deformation during the ES process. The weakening of the basal texture is expected to enhance the formability of $\mathrm{Mg}$ alloys.

Compression and tensile fracture experiments were conducted at room temperature. The fracture behaviors
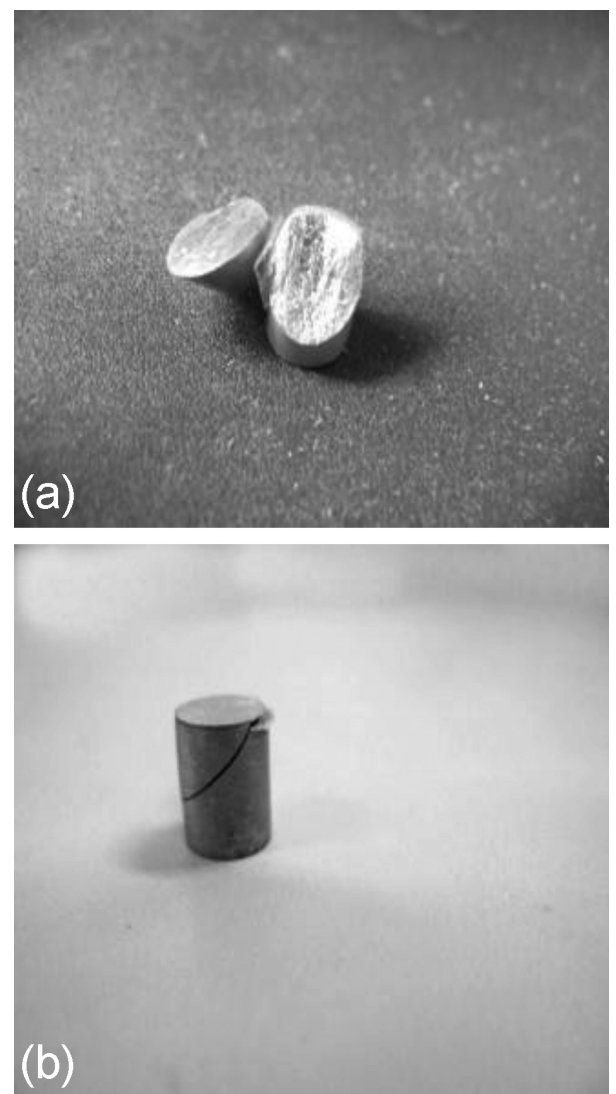

Figure 4: Images of the specimens after compression Slika 4: Posnetek vzorcev po stiskanju

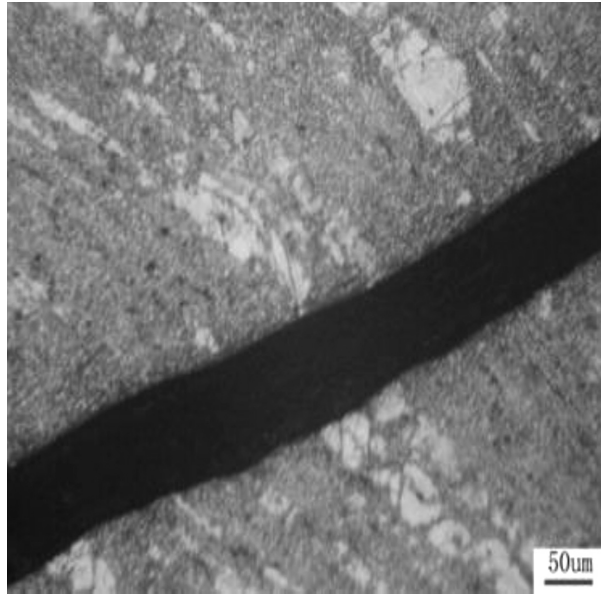

Figure 5: Microstructures of fracture caused by compression in the specimen extruded at $420{ }^{\circ} \mathrm{C}$

Slika 5: Mikrostrukture ob prelomu, ki je nastal pri stiskanju vzorca, iztiskanega na $420{ }^{\circ} \mathrm{C}$

and the regulation of magnesium alloys during the ES process were studied by observing and analyzing the fracture phenomenon, which is important in effectively preventing fractures of the magnesium alloy during the ES process. Macro images of specimens after compression have been shown in Figure 4.

As can be seen from Figure 5, the main fracture of the specimen extruded at $420{ }^{\circ} \mathrm{C}$ is a transgranular fracture, while it is mainly caused by the twins when the extrusion temperature is $450{ }^{\circ} \mathrm{C}$ in Figure 6. The specimen that was formed at $450{ }^{\circ} \mathrm{C}$ would be fractured when the amount of deformation is $10.5 \%$, while the specimen that was formed at $420{ }^{\circ} \mathrm{C}$ would fracture when the amount of deformation is $13.8 \%$.

The microstructures were refined at an extrusion temperature of $420{ }^{\circ} \mathrm{C}$. Twins were hardly generated in the part for dynamic recrystallization. The internal microstructures of the specimens extruded at $450{ }^{\circ} \mathrm{C}$ are uneven, and there is a portion of elongated grains and a

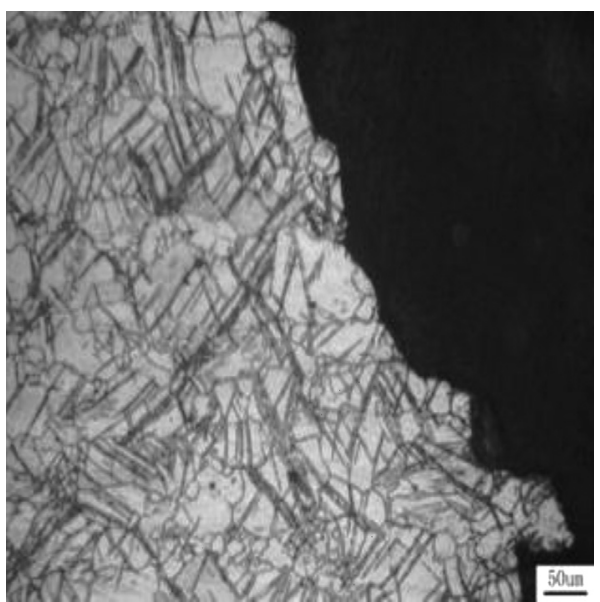

Figure 6: Microstructures for fracture caused by compression in the specimen extruded at $450{ }^{\circ} \mathrm{C}$

Slika 6: Mikrostrukture ob prelomu, ki ga je povzročilo stiskanje vzorca, iztiskanega na $450{ }^{\circ} \mathrm{C}$ 
large amount of fine dynamic-recrystallization grains distributed among the original grains. The specimens would be subjected to a compressive stress during the compression process at room temperature. Once the slip plane tended to the direction that is parallel to the force direction, the slip systems in the magnesium alloy would stop moving. The increase in the external force usually led to the occurrence of twins. The twins were generated between the elongated original grain boundaries. Once the twins occur, due to changes of the crystal orientation in the twins, the slip plane is no longer parallel to the direction of force, and the primary slip systems would begin. The plastic deformation would not stop before the sample is fractured. When the cracks on the edge of the fracture encounter twins, the expansion path is forced to change. Obviously, the hindrance of twins to the crack propagation leads to an improvement in the material toughness. Cracks on the fracture would be hindered by grain boundaries when they encounter small grains. It is known that the microstructures are inhomogeneous. Twins would be generated among the elongated original grains boundaries. However, it is prone to produce cracks in the twin boundaries. It can be seen from Figure 6 that a large amount of twins appear near the fracture and the cracks. A large number of twins were generated along the elongated grain boundaries near the fracture. There are interactions between the twins and cracks, and the cracks could induce twins, and twins would promote crack nucleation. The twins and cracks develop rapidly, so a large stress concentration would occur at the tip of the cracks. Twinning and fracture are two processes that release stress concentration. Therefore, the factors in favor of one process are beneficial to the other process. The microstructures would be elongated under tensile stress and a large number of fine twins would be generated because of the severe deformation at the elongated grain boundaries.

The ES process is actually a combination of extrusion and ECAP extrusion to achieve a compound of extrusion and shear processes. In the early extrusion, the microstructures appear to be bent and broken under simultaneous compression and shear.

\section{CONCLUSIONS}

To study the effects of extrusion-shear on the microstructures and mechanical properties of a magnesium alloy in the homogenized state during the ES process, the ES process was performed on extrusion equipment with the explored ES die. The grain size measurement and the $\mathrm{X}$-ray diffraction analysis, compression experiments and fracture analysis were made and discussed. It can also be seen that the grains are constantly refined from part 1 to 4. The ES process could improve the dynamic recrystallization during deformation. The microstructures become more uniform and finer, when compared to the original states, during the ES process. A higher preheating temperature could improve the grain growth and coarsen the grains. The texture analysis showed that after the ES process there is a variety of types of texture, which could weaken the dominant position the of the basal plane texture (0002). The main fracture mechanism of the specimen extruded at $420{ }^{\circ} \mathrm{C}$ is transgranular fracture, while it is mainly caused by the twins when the extrusion temperature was $450{ }^{\circ} \mathrm{C}$.

\section{Acknowledgements}

This work was supported by the open fund for Key Laboratory of Manufacture and Test Techniques for Automobile Parts (Chongqing University of Technology) Ministry of Education in 2013, and foundation of the post doctorate in Chongqing city and Project Number is Xm201327, the China Postdoctoral Science Foundation funded project, and the Chongqing Natural Science Foundation Project of cstc2014jcyjA50004.

\section{REFERENCES}

${ }^{1}$ G. Liu, J. Zhou, J. Duszczyk, Finite element analysis of magnesium extrusion to produce a cross-shaped profile, J. of Manufacturing Science and Engineering, 129 (2007) 3, 607-614, doi:10.1115/ 1.2714590

${ }^{2}$ H. Hu, D. Zhang, F. Pan, M. Yang, Analysis of the Cracks Formation on Surface of Extruded Magnesium Rod Based on Numerical Modeling and Experimental Verification, Acta Metallurgica Sinica, 22 (2009) 5, 353-364, doi:10.1016/S1006-7191(08)60109-X

${ }^{3}$ K. Siegert, S. Jäger, M. Vulcan, C. Wizemann, Forming tubes, extrusions and sheet metal from magnesium AZ31, Mater. Sci. Forum, 488-489 (2005), 499-508, doi:10.4028/www.scientific.net/MSF. 488-489.499

${ }^{4}$ H. Hongjun, Z. Dingfei, Y. MingBo, D. Ming, 201.Grain refinement in AZ31 Magnesium alloy rod fabricated by an ES SPD process, Transactions of Nonferrous Metals Society of China, 21 (2010) 2, 243-249, doi:10.1016/S1003-6326(11)60705-X

${ }^{5}$ L. Li, J. Zhou, J. Duszczyk, Determination of a constitute relationship for AZ31B magnesium and validation through comparison between simulated and real extrusion, Mater. Process. Technol., 172 (2006) 3, 372-380, doi:10.1016/j.jmatprotec.2005.09.021

${ }^{6}$ M. Chandrasekaran, Y. M. Shyan John, Effect of materials and temperature on the forward extrusion of magnesium alloys, Mater. Sci. Eng. A, 381 (2004), 308-319, doi:10.1016/j.msea.2004.04.057

${ }^{7}$ N. Ogawa, M. Shiomi, K. Osakada, Forming limit of magnesium alloy at elevated temperatures for precision forging, Int. J. Mach. Tools Manu, 42 (2002) 5, 607-614, doi:10.1016/S0890-6955(01) 00149-3

${ }^{8}$ R. Ye. Lapovok, M. R. Barnett, C. H. J. Davies, Construction of extrusion limit diagram for AZ31 magnesium alloy by FE simulation, J. Mater. Process. Technol., 146 (2004) 3, 408-414, doi:10.1016/j.jmatprotec.2003.12.003

${ }^{9}$ S. B. Xu, G. Q. Zhao, X. W. Ma, G. C. Ren, Finite element analysis and optimization of equal channel angular pressing for producing ultra-fine grained materials, Journal of Materials Processing Technology, 184 (2007) 1-3, 209-216, doi:10.1016/j.jmatprotec. 2006.11.025

${ }^{10}$ R. Matsumoto, K. Osakada, Development of warm forging method for magnesium alloy, Materials Transactions, 45 (2004) 9, 2838-2844, doi:10.2320/matertrans.45.2838

${ }^{11}$ D. Orlov, G. Raab, T. T. Lamark, M. Popov, Y. Estrin, Improvement of mechanical properties of magnesium alloy ZK60 by integrated extrusion and equal channel angular pressing, Acta Materialia, 59 (2011) 1, 375-385, doi:10.1016/j.actamat.2010.09.043 